\title{
中赤外フェムト秒光パルスによる水分子ダイナミクスの追跡
}

\author{
芦原 聡 1,2 \\ '東京農工大学大学院 共生科学技術研究院（干184-8588 東京都小金井市中町2-24-16） \\ ²科学技術振興機構(JST) さきがけ（テ332-0012 埼玉県川口市本町4-1-8 川口センタービル)
}

\section{Molecular Vibrational Dynamics in Liquid Water Observed by Mid-Infrared Ultrafast Spectroscopy}

\author{
Satoshi ASHIHARA ${ }^{1,2}$ \\ ${ }^{1}$ Institute of Symbiotic Science and Technology, Tokyo University of Agriculture and Technology, 2-24-16, Naka-cho, Koganei, Tokyo 184-8588 \\ ${ }^{2}$ PRESTO, Japan Science and Technology Agency (JST), 4-1-8, Honcho, Kawaguchi-shi, Saitama 332-0012
}

(Received September 14, 2009)

\begin{abstract}
Nonlinear vibrational spectroscopy by use of mid-infrared femtosecond pulses enables the observation of ultrafast vibrational/structural dynamics of molecular systems in condensed phases. This article presents the recent experimental studies on vibrational energy relaxations and energy transfer in liquid water. In pure liquid water, vibrational energy relaxation of $\mathrm{OH}$-stretching and $\mathrm{OH}$-bending excitation occurs at about $200 \mathrm{fs}$ and $170 \mathrm{fs}$, respectively. When vibrational energy from individually excited water molecules is transferred to intermolecular modes, a sub-100 fs nuclear rearrangement occurs, leaving the local hydrogen bonds weakened but unbroken. Subsequent energy delocalization over many molecules proceeds with the breaking of hydrogen bonds on an 1-ps time scales. The observed vibrational/structral response should be relevant for chemical reactions and structural changes in aqueous environments.
\end{abstract}

Key Words: Water, Vibrational spectroscopy, Molecular dynamics, Ultrashort optical pulses, Midinfrared light

1. はじめに

カーレンズモード同期の発見以来, 超短パルス電磁波 の発生技術は目覚ましく進歩した。今日では中赤外波長 域 $2.5 \sim 25 \mu \mathrm{m}$ (波数 $4000 \sim 400 \mathrm{~cm}^{-1}$ ) でも安定した超短パ ルス発生が可能になり, 可視〜近赤外域と同様, フェム ト秒パルスを利用した非線形分光の研究が進展してい る。よく知られている通り, 中赤外波長域にはさまざま な分子振動モードの共鳴線が存在する. そのため, 赤外 吸収による振動スペクトルを観察すると, 分子の構造や 周囲の環境について知ることができる。短い時間幅をも つ中赤外パルスを利用すると, 非線形光学過程による分 光計測ができるようになり, ダイナミクスの情報が得ら れる. すなわち, 分子の構造変化や振動緩和といった高 速現象を高い時間分解能で観察できるようになる (Fig. $1)^{1,2)}$. 化学反応のメカニズム, あるいは生命活動を 担っている分子の機能を理解する上で, このようなダイ ナミクスに関する知見が重要である。そこで, 最近では タンパク質, DNAや水など, 生命現象に深く関わる水 素結合分子系の高速ダイナミクスに興味が持たれてい る.
水は，生命の維持に欠かせない物質と言われる。事 実，水は生体分子をとりまいて立体構造の形成や化学反 応に関与している，水の中では，水素結合ネットワーク が高密度に張り巡らされており, その構造が絶えず摇ら いでいる。また，生命現象が起こる各場面では，エネル ギーの授受をともなう非平衡ダイナミクスが起こってい

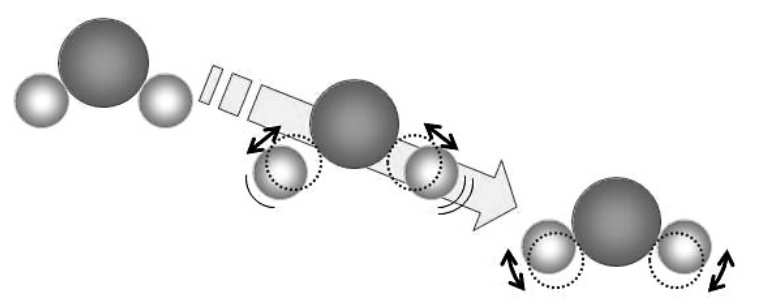

Nonlinear vibrational spectroscopy reveals. Molecular vibrational relaxation,
Structural changes, Anharmonic couplings, Fluctuation of hydrogen bonds, etc.

Fig. 1 Molecular vibrational/structural dynamics observed by mid-infrared optical pulses. 
る. 中でも, 分子振動エネルギー緩和 (特定の分子振動 のエネルギーが分子内外の各運動の自由度に再配分され る過程) は，系の熱平衡化やエネルギー伝達を決定づけ， 化学反応に大きな影響を与える重要な物理化学現象であ る.

本稿では, 赤外域での非線形分光法について解説し, 著者らが解明した水分子の振動緩和ダイナミクスについ て紹介する。

\section{2. 赤外非線形分光法}

\section{1 光 源}

凝縮相中での分子の構造変化や振動緩和は, フェムト 秒〜ピコ秒の時間スケールでおこる，また，測定対象と なる分子振動の共鳴線は中赤外波長域に広く分布する. そこで, 非線形振動分光計測には, 中赤外域で波長が可 変で, マイクロジュール以上のエネルギーをもち, 時間 幅の短いパルス光源が必要となる。現在最も主流となっ ている手法は, チタン・サファイアレーザー増幅システ ムを基とし, BBO結晶中の光パラメトリック増幅 (Optical parametric amplification: OPA)に続けて $\mathrm{AgGaS}_{2}$ あい はGaSe結晶を用いた差周波発生(Difference frequency generation: DFG)を行うものである(Fig. 2)。これによ り，波長3-18 umで可変，パルス幅100２00 fsの中赤外 パルスが得られる ${ }^{3,4)}$. $\mathrm{OH}, \mathrm{NH}, \mathrm{CH}$ 基の伸縮振動モー ドの共鳴線が存在する波長3-4 $\mu \mathrm{m}$ では, $\mathrm{KTiPO}_{4}$ 結晶(ま たは $\mathrm{KNbO}_{3}$ 結晶や周期分極反転 $\mathrm{LiNbO}_{3}$ 素子) を利用した OPAによって直接, 中赤外パルスを発生させることもで きる ${ }^{5-7)}$.

\section{2 赤外非線形分光法}

凝縮相中の分子ダイナミクス(励起状態の寿命や振動 遷移の摇らぎなど)を観測する上で，ポンプ・プローブ 法やフォトン・エコー法など, 三次の非線形光学効果を 利用した赤外分光法が有用である ${ }^{1,2)}$. 赤外ポンプ・プ ローブ法を利用すると, 分子振動の励起寿命や分子内・ 分子間でのエネルギー移動, 非調和カップリングなどの 情報が得られる。 また, 赤外フォトン・エコー法を用い ると，遷移エネルギーが摇らぐ特徵的な時間を測定でき るため，いわゆる線幅の均一広がりを測定できる。つま り, FTIR法で観測される線幅広がりについて, 均一広 がりと不均一広がりの区別を可能にする。最近普及して きた手法として，赤外二次元相関分光が挙げられる(例 えば文献8を参照)。これは二次元NMRの原理を振動遷 移に適用したものであり, 振動モードの相関や均一・不

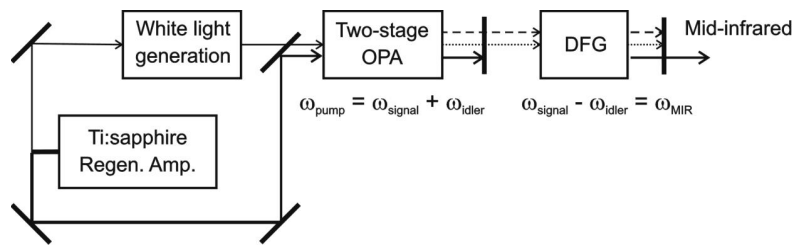

Fig. 2 Schematic of the MIR pulse generation by whitelight seeded OPA and DFG.
均一広がりの区別，スペクトル拡散を調べる上で有用で ある。

ここでは，以下の測定に用いた中赤外ポンプ・プロー ブ分光法について詳述する，ポンプ光が分子を振動励起 し，時間遅延をもって入射したプローブ光が分子の振動 状態や構造, 水素結合状態を観測する (Fig. 3 (a))。第 一振動励起状態 $(v=1)$ に励起された分子は, $v=0 \rightarrow 1$ 遷移に対応する吸収の飽和 (ブリーチ) , $v=1 \rightarrow 0$ 遷移 に対応する誘導放出，そして $v=1 \rightarrow 2$ 遷移に対応する 励起状態吸収という三種類の吸収変化を生み出す。一般 に, 振動ポテンシャルには非調和性が存在するため, $v=1 \rightarrow 2$ の遷移エネルギーは $v=0 \rightarrow 1$ のそれと比べて 小さくなる (Fig. 3 (b)). このため, 振動が励起される と共鳴振動数では吸収が減少し, 低振動数の領域で吸収 が増加する。 これらの振幅が減衰する様子から励起状態 の寿命 (エネルギー緩和時間)がわかる。 また，励起した モードとは異なる振動モードの吸収変化を測定すること で(二色ポンプ・プローブ分光測定)，エネルギーがモー ド間を移行するダイナミクスや非調和カップリングを観 測できる。

\section{3. 水の振動緩和ダイナミクスの観測}

\section{1 当該研究の経緯}

Fig. 4に液相での水 $\mathrm{H}_{2} \mathrm{O}$ の赤外吸収スペクトルを示 $す^{9)}$. 高振動数側から $\mathrm{OH}$ 伸縮振動 (逆対称および対称 モード), 結合音, $\mathrm{OH}$ 変角振動, 束縛回転振動 (Libration）に対応するピークが存在する。この束縛回転振動 は，水素結合を介して周囲分子と協同的に振動する分子 間振動の一つである。束縛回転振動モードは $670 \mathrm{~cm}^{-1}$ を 中心とする主要バンド(L2バンド)から高振動数側へ裾

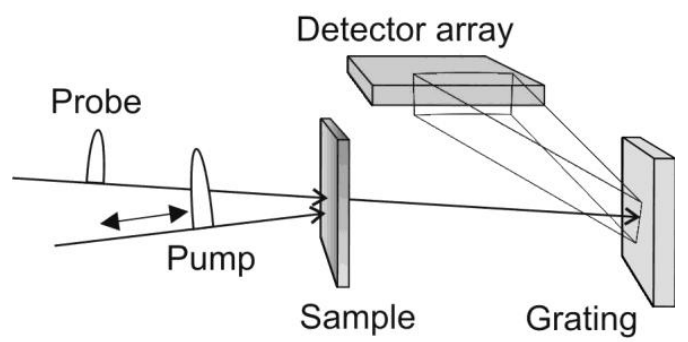

(a)

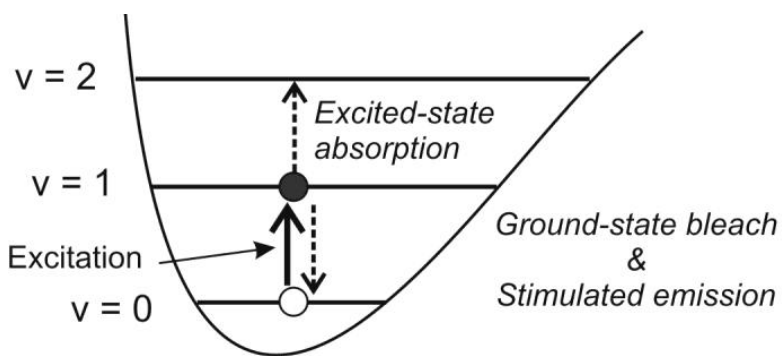

(b)

Fig. 3 (a) A schematic of the mid-infrared pump-probe spectroscopy. (b) Vibrational energy levels in an anharmonic potential and the observable transitions. 


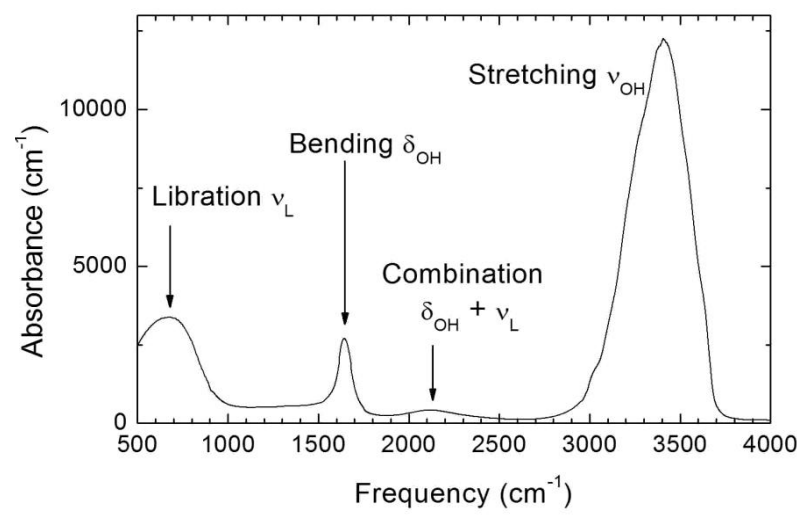

Fig. 4 Infrared absorption spectrum of liquid $\mathrm{H}_{2} \mathrm{O}$ at room temperature. ${ }^{9}$

野を伸ばし， $1700 \mathrm{~cm}^{-1}$ ありまで続く，各バンドは， 振動励起状態の寿命や位相緩和時間に加え, 低振動数 モードとの非調和カップリング, 水素結合の不均一性な どによってスペクトルが広がっている。

1998年, Bakkerら ${ }^{10)}$ は赤外ポンプ・プローブ実験によ り, $\mathrm{HOD}$ 分子 $\left(\mathrm{HOD}: \mathrm{D}_{2} \mathrm{O}\right)$ の $\mathrm{OH}$ 伸縮振動モードの励起寿 命が約700 fsであることを明らかにした，その後，約 10 年の間に, 水の振動緩和現象が一つずつ解明されてき た ${ }^{10-20)}$. 例えば, $\mathrm{H}_{2} \mathrm{O}$ の OH伸縮振動モードは約 $200 \mathrm{fs} の$ 励起寿命をもち, 分子間で共鳴的なエネルギー移行を起 こすことが知られている ${ }^{12-15)}$ 、筆者らは，まず，もう一 つの分子内振動である $\mathrm{OH}$ 変角振動モードの励起寿命が 約170 fsであることを明らかにした ${ }^{16)}$. 振動緩和現象の 全貌を解き明かす上で，これら分子内モードの励起寿命 だけでなく，分子内モードから分子間モードへ，あるい は分子間モードの間でエネルギーが移行するダイナミク スについての知見が不可欠である。そこで，筆者らは， ポンプ・プローブ分光の測定領域を低振動数側へ拡大 し, 束縛回転振動モードの過渡吸収応答の観測を行っ $た^{19)}$.

\section{2 実験装置}

Fig. 2 と同様, チタン・サファイアレーザーの再生増 幅器と光パラメトリック増幅(Type II, BBO)および差周 波発生(Type I, $\mathrm{AgGaS}_{2}$ or $\mathrm{GaSe}$ ) 利用して, 時間幅約 $100 \mathrm{fs}$ の赤外パルスを発生した $(3-18 \mu \mathrm{m}$ で波長可 変)。この波長変換システムを二つ利用することで, ポ ンプ光とプローブ光の波長を独立に制御した．ポンプ. プローブ遅延時間をスキャンしながら，プローブ光の透 過スペクトルを分光器と $\mathrm{HgCdTe}$ 検出器アレイにより測 定し, 過渡的な吸収変化 $\Delta A$ を各遅延時間において算出 した。半導体InAs結晶中のフリーキャリアに起因する光 誘起吸収変化を利用して装置の時間分解能を評価した結 果, 約 $150 \mathrm{fs}$ であった。試料の超純水 $\mathrm{H}_{2} \mathrm{O}$ は空材 (厚さ $0.8 \mu \mathrm{m} の \mathrm{Si}_{3} \mathrm{~N}_{4}$ 膜) の間に閉じ込め, その厚みを3-7 $\mu \mathrm{m} に$ 調整した。振動数 $1000 \mathrm{~cm}^{-1}$ 以下で測定するときには, 適切な空材が無いため, 二本のステンレス線の間に形成 した石けん水の膜を試料とした。

\subsection{OH変角振動モードの励起寿命}

中心振動数 $1650 \mathrm{~cm}^{-1}$ の光パルスを利用し, $\mathrm{OH}$ 変角振 動モードの一色ポンプ・プローブ分光測定を行った。過 渡的な吸収変化スペクトルをFig. 5(a)に示す。励起直 後, $1650 \mathrm{~cm}^{-1}$ 付近に吸収の減少が, その低振動数側に 吸収の増加が見られる。この $1650 \mathrm{~cm}^{-1}$ 付近に現れる吸 収の減少は, 基底状態吸収 $(v=0 \rightarrow 1)$ のブリーチと誘 導放出 $(v=1 \rightarrow 0)$ に起因する。 また, 低振動数側に現 れる吸収の増加は, $v=1 \rightarrow 2$ 遷移に相当する励起状態 吸収である。この傾向は300 fs 程度で消え, その後 $1 \mathrm{ps}$

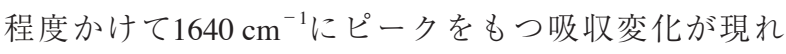
る。 ピコ秒程度でゆるやかに発展する吸収変化は, エネ ルギーがあらゆる運動の自由度に再配分されて熱平衡状 態(温度が上昇した状態)に達する過程と解釈できる。そ れぞれ1560, $1650 \mathrm{~cm}^{-1}$ での吸収変化の過渡信号をFig. 5 (b)に示す。これらの過渡信号を, 励起寿命 $T_{1}$ で減衰す る成分と熱平衡化 (時定数 $T_{\mathrm{th}}$ )を示す成分を含んだ式 $A_{1}$ $\exp \left[-\left(t / T_{1}\right)\right]+A_{2}\left\{1-\exp \left[-\left(t / T_{\mathrm{th}}\right)\right]\right\}$ でフィッティング することで, $\mathrm{OH}$ 変角振動モードのエネルギー緩和時間 $T_{1}=170 \pm 30 \mathrm{fs}$ を得た. 対象的に, $\mathrm{H}_{2} \mathrm{O}$ 分子の $\mathrm{OH}$ 変角振 動モードの励起寿命が, 無極性溶媒中では8.5 psである

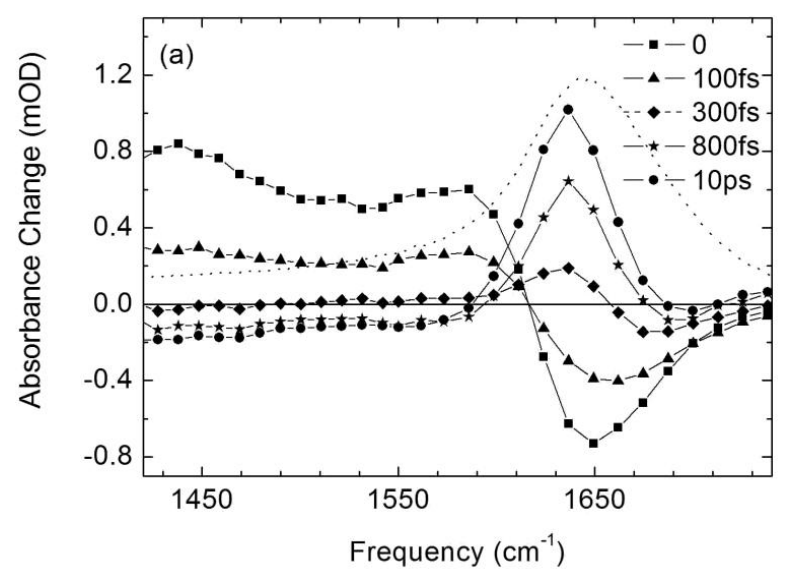

(a)

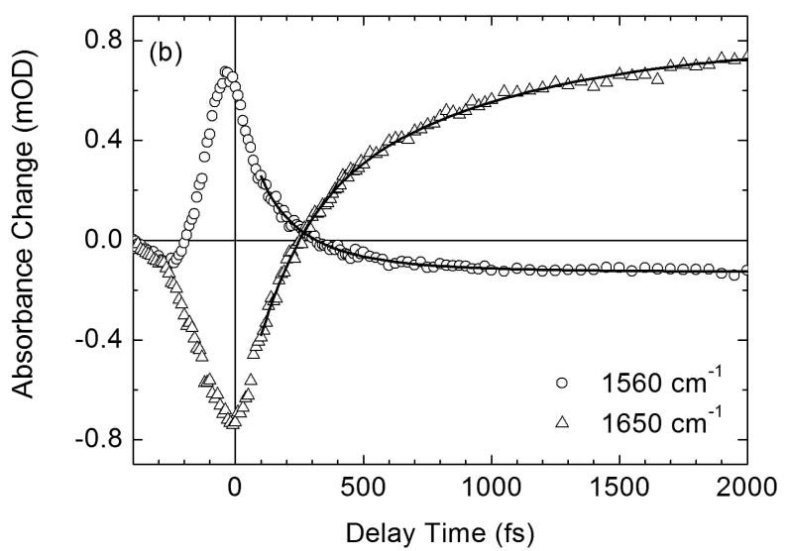

(b)

Fig. 5 (a) Transient vibrational spectra of $\mathrm{H}_{2} \mathrm{O}$ measured with pump pulses centered at $1650 \mathrm{~cm}^{-1}$. The linear absorption spectrum is shown as a dotted line for comparison. (b) Time resolved absorbance change at probe frequencies of 1560 and $1650 \mathrm{~cm}^{-1}$, respectively. ${ }^{16)}$ 
ことが報告されている ${ }^{211}$ 。このことから，今回観測され た純粋な $\mathrm{H}_{2} \mathrm{O}$ 中での $\mathrm{OH}$ 変角振動モードの高速なエネル ギー緩和は，OH変角振動モードと分子間振動モードと の間の強い非調和カップリングに起因すると考えられる。

\section{4 束縛回転振動モードの応答}

ポンプ光によって束縛回転振動モードの高振動数領域 $\left(1350 \mathrm{~cm}^{-1}\right), \mathrm{OH}$ 変角振動モード $\left(1650 \mathrm{~cm}^{-1}\right), \mathrm{OH}$ 伸縮 振動モード $\left(3150 \mathrm{~cm}^{-1}\right)$ をそれぞれ励起した各場合につ いて, 振動数 $560 \sim 1750 \mathrm{~cm}^{-1}$ の過渡吸収信号を測定し た. Fig. 6 (a)にはプローブ領域に扔ける $\mathrm{H}_{2} \mathrm{O}$ の赤外吸収 スペクトルを, Fig. $6(\mathrm{~b}-\mathrm{d})$ には測定した過渡吸収スペ クトルを示す。束縛回転振動モードの励起直後, 950$1500 \mathrm{~cm}^{-1}$ にわたって吸収が増加する。 ポンプ光の振動 数 $1350 \mathrm{~cm}^{-1}$ 付近では, 瞬間的に立ち上がった吸収変化 は時間分解能以内に消失し, さらにサブピコ秒の時間入 ケールで緩やかに変化する．560-950 $\mathrm{cm}^{-1}$ での吸収変化 はL2バンドのブリーチングか, あるいは低振動数側へ シフトを表している. 変角振動モードや伸縮振動モード を励起した際にもL2バンドの同様なスペクトル変化は

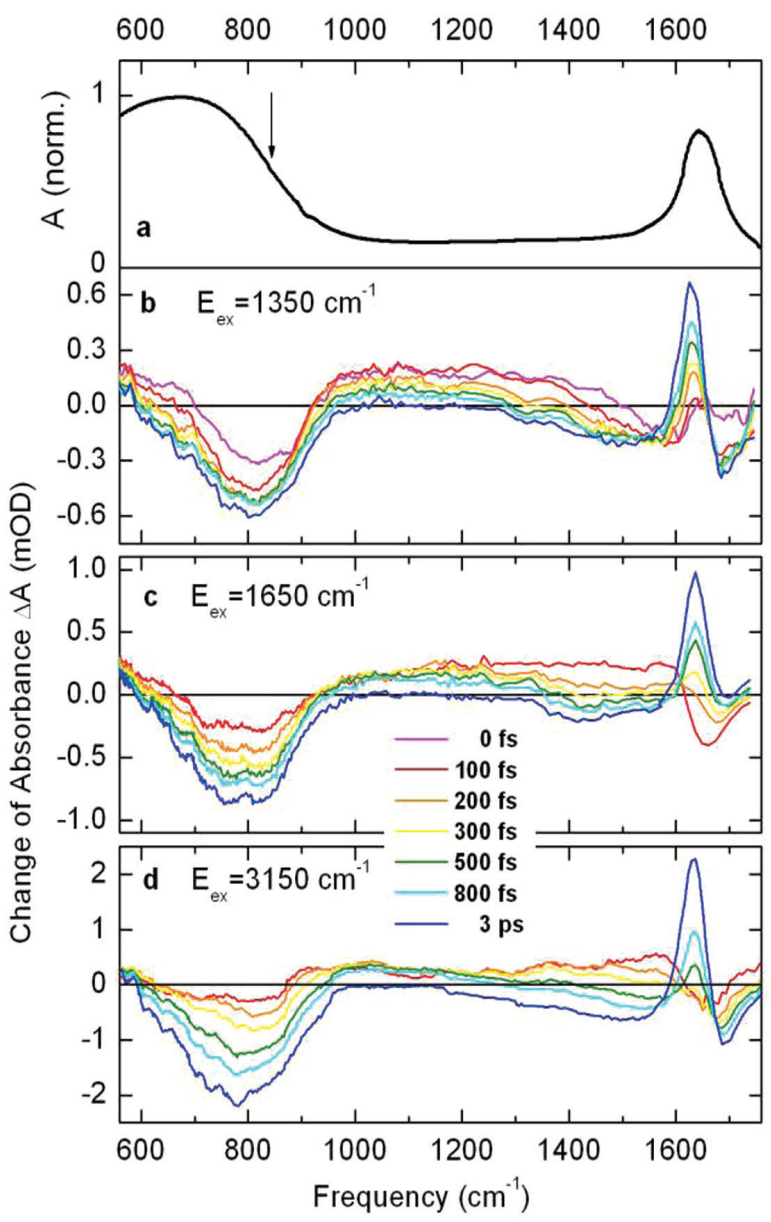

Fig. 6 (a) Linear absorption spectrum of liquid $\mathrm{H}_{2} \mathrm{O}$. The arrow shows the probe frequency whose transient signals are shown in Fig. 7. Transient absorption spectra are shown for excitation of (b) high-frequency libration, (c) $\mathrm{OH}$ bending mode, (d) $\mathrm{OH}$ stretching mode $\left(\mathrm{E}_{\mathrm{ex}}\right.$ : center frequency of the pump pulse). ${ }^{19)}$
現れるが，以下に示すとおり，それらの時間発展に著し い違いが見られた。

Fig. $7(\mathrm{a}-\mathrm{c})$ に，それぞれの励起条件で観測したプロー ブ振動数 $840 \mathrm{~cm}^{-1}$ での過渡吸収信号を示す。束縛回転振 動の高振動数成分を励起した場合（Fig. 7 (a))，時間分 解能 $100 \mathrm{fs}$ 以内に吸収変化が立ち上がり，その後900 fs程 度の時定数で緩やかに発展する。変角振動モード励起時 (Fig. 7 (b)) には, 変角振動モードの励起寿命である $170 \mathrm{fs}$ で吸収変化が立ち上がり, 続けて900 fsの時定数で 発展する。OH伸縮振動モードを励起した場合 (Fig. 7 (c)）には, さらに伸縮振動モードの励起寿命 $200 \mathrm{fs}$ だけ 遅れて吸収変化が立ち上がり，その後は他の場合と同様 に900 fsの時定数で発展する。

以上の結果を考察しょう. Fig. 7 (a)に示した通り, $1350 \mathrm{~cm}^{-1}$ で励起したときL2バンドの吸収変化は $100 \mathrm{fs}$ 以 内に立ち上がる。これは, 束縛回転振動モードの励起工 ネルギーが100 fs以内に緩和し， L2 2バンド内の低振動数 モードを含めた，他の分子間振動モードに移行している ことを示唆している。個々のモードの励起寿命が短いた め, 励起状態のポピュレーションは増えず, ブリーチや 誘導放出による吸収変化は小さいと考えられる。する と, 初期 $(<100 \mathrm{fs})$ に現れる吸収変化の支配的な要因は, 束縛回転振動の自由度の範囲内でエネルギー再配分が起 こったことによるL2バンドのレッドシフトと考えられ

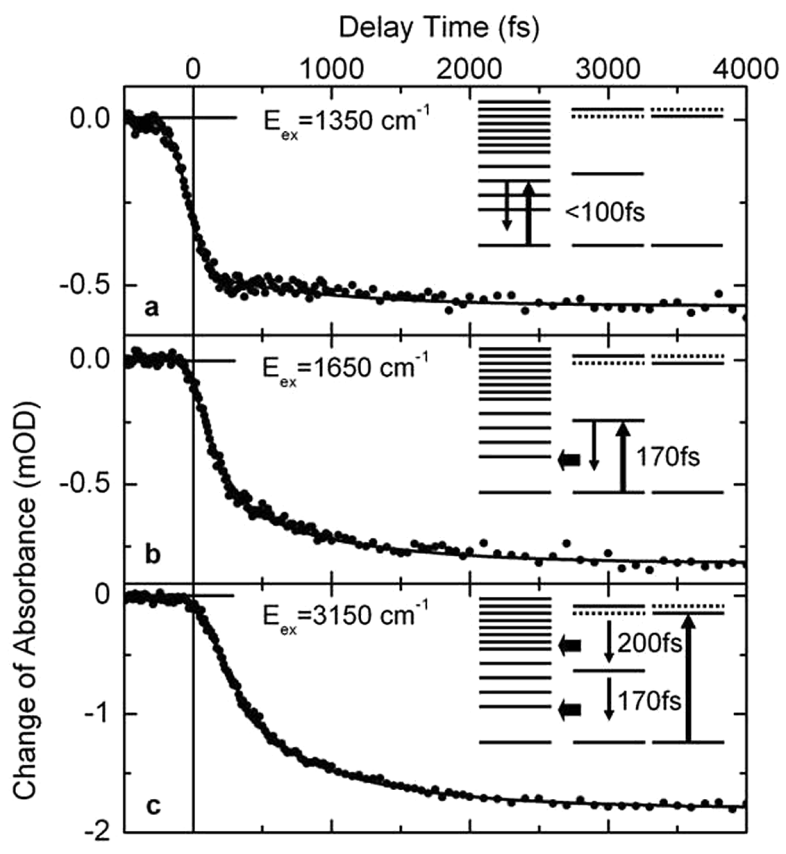

Fig. 7 Change of librational absorbance at $840 \mathrm{~cm}^{-1}$ as a function of pump-probe delay after excitation of (a) high-frequency librations, (b) the $\mathrm{OH}$ bending mode, and (c) the $\mathrm{OH}$ stretching mode (solid circles). The kinetics of the initially excited modes determine the rise of $\Delta A$ as illustrated by the level schemes (insets) and reproduced by numerical calculations (solid lines) with the lifetimes of the $\mathrm{OH}$ stretching mode (200 fs), OH bending mode (170 fs), high-frequency librations (<100 fs), and a 0.9 ps energy delocalization kinetics. ${ }^{19)}$ 
る.このエネルギー再配分が起こると, 励起された水分 子周辺の原子核の配置 (液体としての構造)が変化し, 水 素結合に歪みや伸張がもたらされる。 その歪みや伸張 が，L2モードのポテンシャルを平坦化させ，バンド全 体をレッドシフトさせていると解釈できる。すると，こ の液体構造の変化に要する時間は, 最短で束縛回転振動 の一周期程度となる。

Fig. $7(\mathrm{a}-\mathrm{c})$ に示されたレッドシフトの立ち上がりは, エネルギーが束縛回転振動モードへ伝達される夕イミン グを表わしている。OH伸縮振動やOH变角振動を励起し た場合には，そのタイミングが分子内振動の励起寿命だ

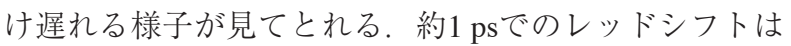
いずれの励起条件においても共通して現れるが, これは マクロな温度の上昇を反映している。すなわち, 振動工 ネルギーが水素結合ネットワークのあらゆる運動の自由 度へと再配分され，エネルギーが多くの分子に散逸する 過程である。

以上をまとめると, 束縛回転振動モードのエネルギー 緩和は非常に短い時間 (<100fs) で起こり, その際, 水 素結合ネットワークに局所的な歪みが生じる。 また，そ の後約 1 psでエネルギーが水素結合ネットワークへと散 逸し, 水素結合の切断が起こる。このような水素結合 ネットワークの変形・切断という二段階の構造変化が, 振動励起をきっかけとして起こることが明らかになっ た。

\section{4. まとめ}

中赤外ポンプ・プローブ分光計測により，水分子の振 動緩和ダイナミクスを測定した。その結果, $\mathrm{OH}$ 変角振 動モードの励起寿命が約 $170 \mathrm{fs}$ であり, 束縛回転振動 モードのエネルギー緩和は $100 \mathrm{fs}$ 以下で起こることがわ かった。これら非常に高速なエネルギー緩和は, 水とい う液体が，分子スケールの空間に局在したエネルギーを 素早く散逸する機能をもつことを表している．水分子の 振動励起は素早く液体構造の変化を誘起するが, その構 造変化は, 水中の溶質分子の環境, ひいては化学反応に も影響を与えていると考えられる. 今日では, 細胞内の 水と同様に，ナノ空間に拘束された水や界面に存在する 水のダイナミクスにも興味が集まっている.

液相分子のダイナミクス研究に関する近年の目覚まし い進展は，光源技術の成熟に負うところが大きい，逆に 言うと，新しい光源技術はさらに分子科学を発展させる 可能性をもつ。 中赤外パルスの広帯域化，高エネルギー 化によって，分子間振動モードの二次元相関分光などと いった高度な測定をも可能にするであろう，また，波形 整形技術が成熟すれば，振動遷移による分子のコヒーレ
ント制御という新しい展開も期待できる。これまで電子 遷移で行われていたコヒーレント制御を振動遷移に広げ ることで，分子制御の自由度が高まるであろう。例え ば，電子的基底状態における結合の切断，元素の同位体 分離，分子の構造異性化といった反応の制御につながる 可能性があり，大変興味深い.

\section{謝 辞}

本稿で紹介した内容の一部は，マックスボルン研究所 において行われた成果です。共同研究者のHuse博士, Espagne博士, Nibbering博士, Elsaesser教授に深く感謝 致します。

\section{参考文献}

1) M. D. Fayer (Ed.): Ultrafast Infrared and Raman Spectroscopy (Marcel Dekker, New York, 2001).

2) E. T. J. Nibbering, T. Elsaesser: Chem. Rev. 104 (2004) 1887.

3) R. A. Kaindl, M. Wurm, K. Reimann, P. Hamm, A. M. Weiner, and M. Woerner: J. Opt. Soc. Am. B 17 (2000) 2086.

4) P. Hamm, R. A. Kaindl, and J. Stenger: Opt. Lett. 25 (2000) 1798

5) U. Emmerichs, S. Woutersen, and H. J. Bakker: J. Opt. Soc. Am. B 14 (1997) 1480.

6) C. J. Fecko, J. J. Loparo, and A. Tokmakoff: Opt. Commun. 241 (2004) 521.

7) S. Ashihara, T. Mochizuki, S. Yamamoto, T. Shimura, and K. Kuroda: Jpn. J. Appl. Phys. 48 (2009) 042501.

8) D. M. Jonas: Annu. Rev. Phys. Chem. 54 (2003) 425

9) D. M. Wieliczka, S. Weng, and M. R. Querry: Appl. Opt. 18 (1989) 1714.

10) S. Woutersen, U. Emmerichs, H.-K. Nienhuys, and H. J. Bakker: Phys. Rev. Lett. 81 (1998) 1106.

11) J. Stenger, D. Madsen, P. Hamm, E. T. J. Nibbering, and T. Elsaesser: Phys. Rev. Lett. 87 (2001) 027401.

12) A. J. Lock and H. J. Bakker: J. Chem. Phys. 117 (2002) 1708.

13) M. L. Cowan, B. D. Bruner, N. Huse, J. R. Dwyer, B. Chugh, E. T. J. Nibbering, T. Elsaesser, and R. J. D. Miller: Nature 434 (2005) 199.

14) S. Woutersen and H. J. Bakker: Nature 402 (1999) 507.

15) D. Kraemer, M. L. Cowan, A. Paarman, N. Huse, E. T. J. Nibbering, T. Elsaesser, and R. J. D. Miller: Proc. Nat. Acad. Sci. 105 (2008) 437.

16) N. Huse, S. Ashihara, E. T. J. Nibbering, and T. Elsaesser: Chem. Phys. Lett. 404 (2005) 389

17) S. Ashihara, N. Huse, E. T. J. Nibbering, and T. Elsaesser: Chem. Phys. Lett. 424 (2006) 66.

18) J. Linder, P. Voehringer, M. S. Pshenichnikov, D. Cringus, D. A. Wiersma, and M. Mostovoy: Chem. Phys. Lett. 421 (2006) 329.

19) S. Ashihara, N. Huse, A. Espagne, E. T. J. Nibbering, and T. Elsaesser: J. Phys. Chem. A 111 (2007) 743.

20) H. J. Bakker, in: Ultrafast Hydrogen Bonding Dynamics and Proton Transfer Processes in the Condensed Phase, ed. T. Elsaesser and H. J. Bakker (Kluwer, Dordrecht, 31, 2002).

21) G. Seifert, T. Patzlaff, and H. Graener: J. Chem. Phys. 120 (2004) 8866 . 